\title{
THE EFFECTS OF PROPANIDID ON ARTERIAL PRESSURE, PULSE RATE, PREGANGLIONIC SYMPATHETIC ACTIVITY AND BAROSTATIC REFLEXES IN THE CAT
}

\author{
Kaj Wisborg, ${ }^{1}$ Sanguan Sapthavichaikul, ${ }^{2}$ and Per Skovsted ${ }^{3}$
}

Propanidid is a Non-Barbiturate intravenous anaesthetic. It is a eugenol derivative rapidly metabolized in the body by plasma cholinesterase. ${ }^{1}$ It has cardiovascular actions similar to those of short-acting barbiturates and Althesin in that it produces myocardial depression and hypotension..$^{2,3,4}$ Since the effect of propanidid on central circulatory control mechanisms has not been investigated this study was done to evaluate to what extent, if any, the cardiovascular actions of propanidid could be explained on the basis of its action upon the autonomic nervous system. Since the method for the study is essentially the same as that previously used in studies of barbiturates ${ }^{5}$ and Althesin ${ }^{6}$ it allows us to compare the cardiovascular and autonomic nervous system actions of these three chemically and pharmacologically different agents.

\section{METHOD}

Sixteen cats weighing 2.3 to $5.5 \mathrm{~kg}$ were used in the experiments. They were initially anaesthetized with halothane by mask while a femoral artery, a femoral vein and the trachea were cannulated. Halothane was then discontinued and decamethonium 2 to $4 \mathrm{mg}$ was given intravenously and repeated every half-hour throughout the experiment. Respiration was controlled with a respirator delivering 50 per cent nitrous oxide and 50 per cent oxygen. Sympathetic nervous activity was recorded from teased strands of preganglionic fibres of the left cervical sympathetic trunk. Details of the method have been described elsewhere. ${ }^{7}$ Arterial pressure was recorded by a Statham P-23D transducer (mean pressures obtained by electrical damping). End-tidal $\mathrm{CO}_{2}$ was measured by a Godart capnograph. Arterial blood samples were drawn prior to the administration of propanidid and analyzed in an IL assembly for $\mathrm{pH}, \mathrm{Pa}_{\mathrm{CO}_{2}}$, and $\mathrm{Pa}_{\mathrm{O}_{2}}$. If metabolic acidosis was present it was corrected with sodium bicarbonate. In all experiments $\mathrm{Pa}_{\mathrm{O}_{2}}$ exceeded 100 torr ( $13.3 \mathrm{kPa}$ ).

The animals were placed on a heating pad so that rectal temperature measured with a Yellow Springs thermister might be kept at $36-38^{\circ} \mathrm{C}$. The following param-

From: Department of Anaesthesiology, Hahnemann Medical College and Hospital of Philadelphia, Philadelphia, Pennsylvania 19102, U.S.A. and Department of Anaesthesia, Rigshospitalet (University Hospital), Blegdamsvej 9, 2100 Copenhagen, Denmark.

Supported in part by NIH Grant No. HI 15392-03.

${ }_{1}$ Kaj Wisborg, M.D., visiting Assistant Professor of Anaesthesia.

2Sanguan Sapthavichaikul, M.D., Senior Instructor of Anaesthesia.

3Per Skovsted, M.D., Assistant Professor of Anaesthesia. Present Address: Department of Anaesthesia, Rigshospitalet Blegdamsvej 9, 2100 Copenhagen, Denmark. 
eters were recorded on a Grass polygraph: arterial pressure, mean arterial pressure, end-tidal $\mathrm{CO}_{: 2,}$ sympathetic nervous activity in impulses per second, and pulse rate measured by a tachograph triggered by the pulse wave.

\section{Experimental Protocol}

Seven "normal" animals were studied. A "normal" animal is defined as one in which only the sympathetic trunk was sectioned. Two of these animals referred to as "hypertensive" were made hypertensive simultaneously with the administration of propanidid by an intravenous injection of nor-epinephrine.

Five baroreceptor-denervated animals were studied. The carotid sinus, aortic depressor and vagus nerves were sectioned in these animals prior to the administration of propanidid. Two animals were placed in a stereotaxic frame under halothane anaesthesia and midcollicular decerebration was done by blunt section. When decerebrate rigidity had occurred the animals were treated as "normal" but received no nitrous oxide.

Two animals were studied without nerve recording with first one and then both vagal nerves sectioned, all other barostatic nerves remaining intact ("vagal" animals). All received two bolus injections of propanidid $6 \mathrm{mg} / \mathrm{kg}$ intravenously. The time between injections was 30 minutes in all instances. All statistical analyses were performed using t-tests. A p-value below 0.05 was considered statistically significant.

In order to compare the cardiovascular depression caused by propanidid in "normal" animals (barostatic reflexes preserved) with that in baroreceptordenervated animals (no barostatic reflexes) the fall in arterial pressure has been expressed both in absolute value and in per cent of initial pressure. The mean values are listed under results.

\section{Results}

\section{Normal animals}

The response of sympathetic nervous activity (SA), mean arterial blood pressure (MABP) and pulse rate to propanidid are shown in Figures 1 and 2. Highest and lowest values indicate peak changes from initial readings found within the first two minutes after injection of propanidid. A marked increase in sympathetic nervous activity was noted from $56.5 \pm 4.5$ to $81.7 \pm 5.3 \mathrm{impulses} / \mathrm{sec}(\mathrm{p}<0.001)$. The increase in sympathetic nervous activity clearly coincided with the decline in arterial pressure and was followed by a decline in activity from $56.5 \pm 4.5$ to $25.0 \pm 1.9$ impulses $/ \mathrm{sec}(\mathrm{p}<0.001)$. Mean arterial blood pressure declined from $153.0 \pm 7.6$ torr $(20.3 \pm 1 \mathrm{kPa})$ to $106.1 \pm 8.6$ torr $(14.1 \pm 1.3 \mathrm{kPa})(\mathrm{p}<0.001)$ after which it increased to $171.4 \pm 9.4$ torr $(22.8 \pm 1.3 \mathrm{kPa})(\mathrm{p}<0.005)$ before returning to the initial level. Pulse rate increased from $197.3 \pm 5.9$ to $247.3 \pm 9.3$ beats $/ \mathrm{min}(\mathrm{p}<0.001)$ after an initial modest decline lasting only 1 second of $197.3 \pm 5.9$ to $192.6 \pm 5.9$ beats $/ \mathrm{min}(\mathrm{p}<0.001)$. Mean arterial pressure and pulse rate returned to a level not significantly different from the initial level within two minutes, while sympathetic activity remained depressed for three more minutes. 
WISBORG, et al.: EFFECTS OF PROPANIDID
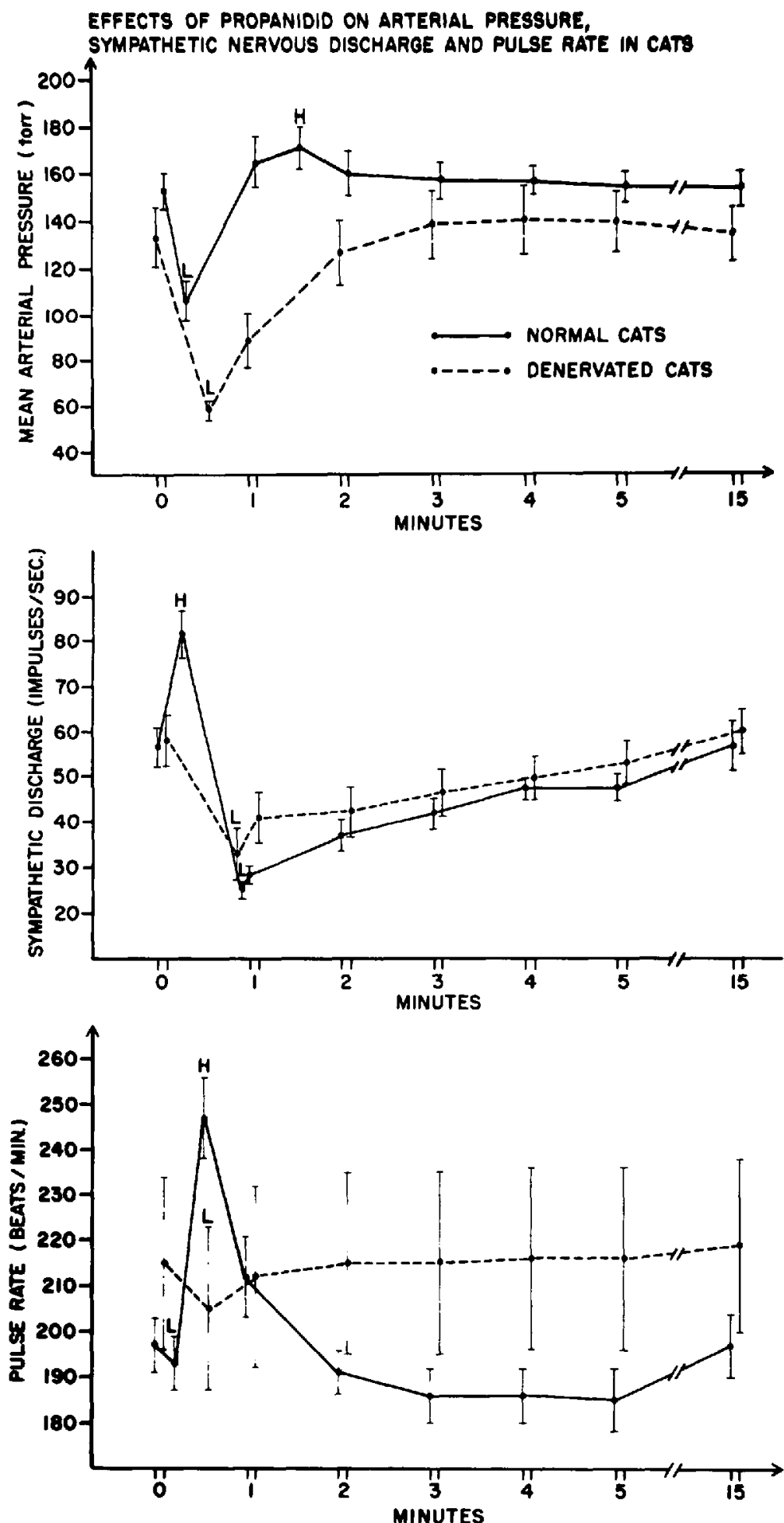

Figure 1. Effects of propanidid on sympathetic nervous activity, mean arterial pressure and pulse rate in normal and baroreceptor denervated cats. 


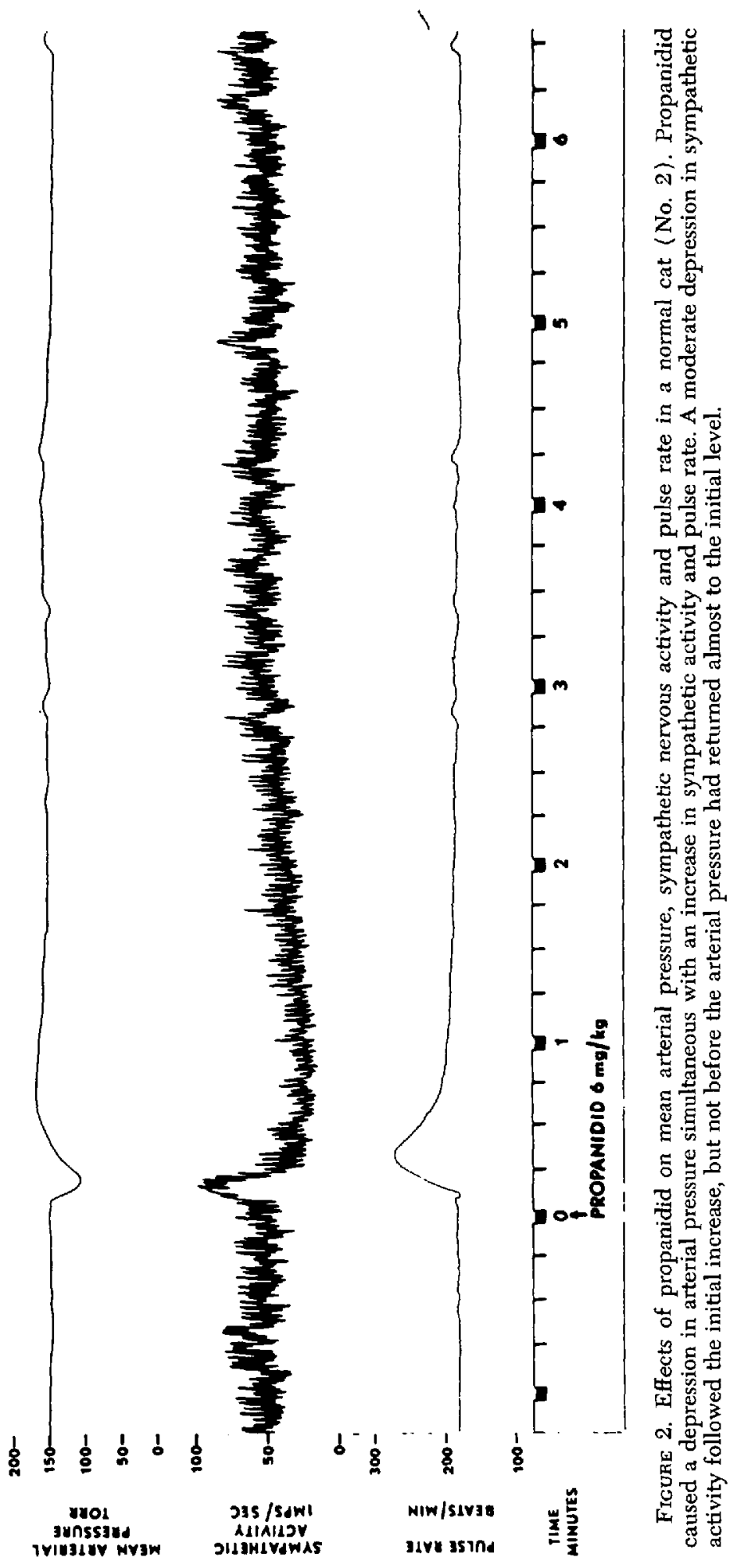




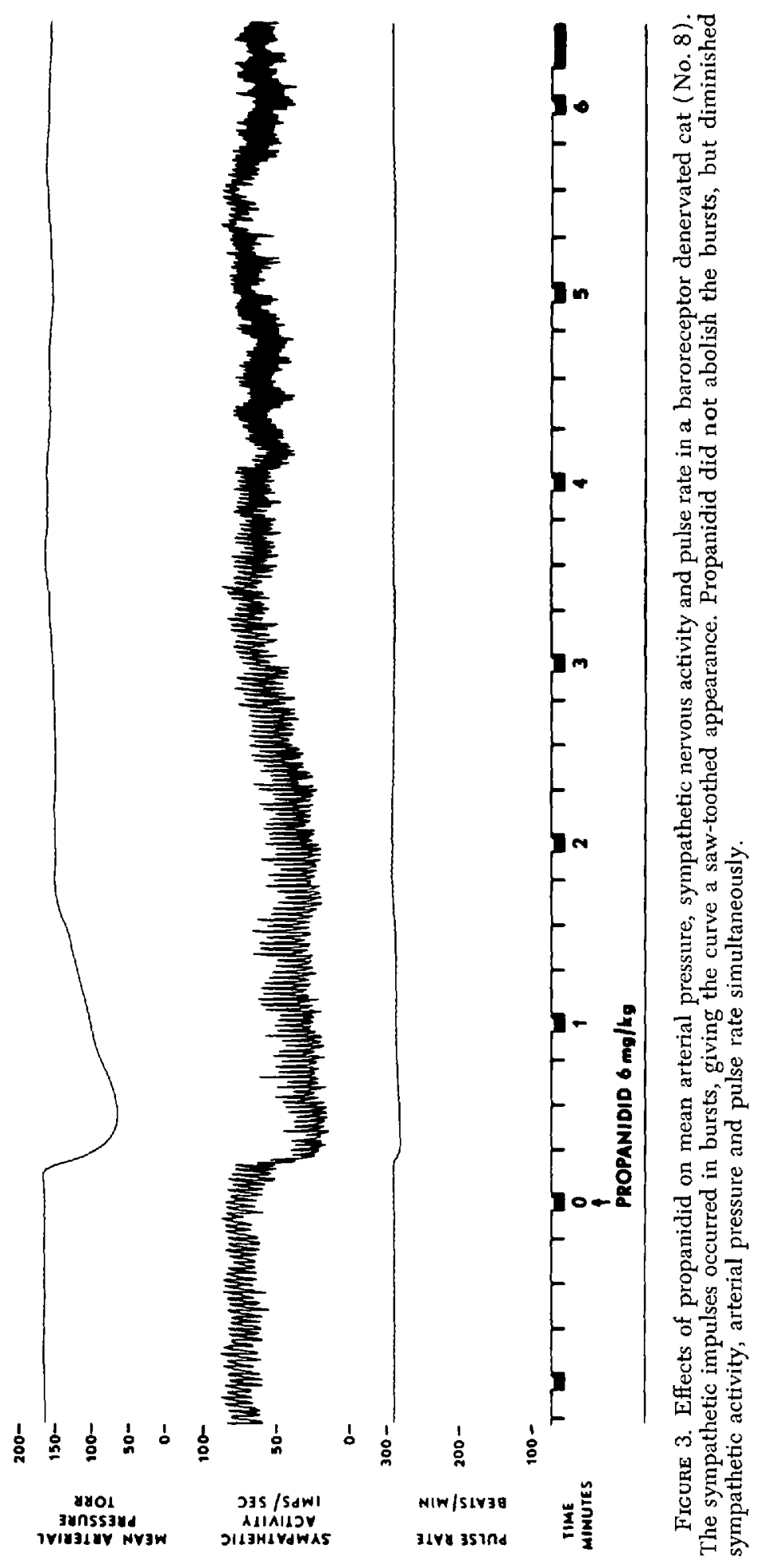




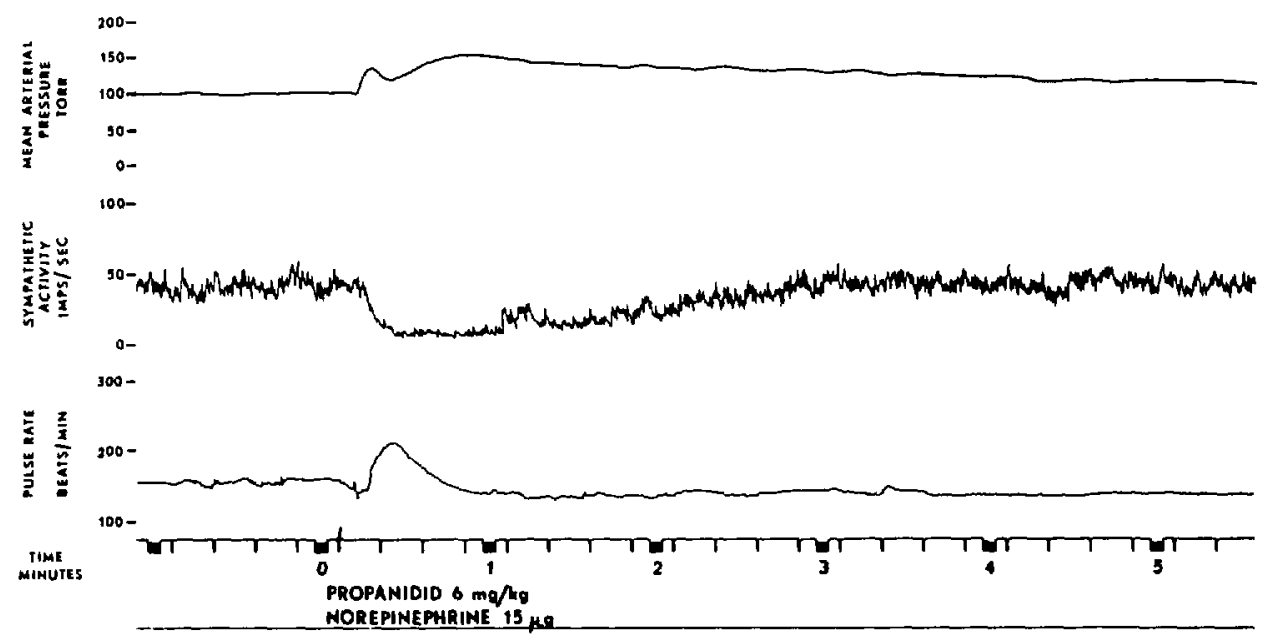

Ficune 4. Effects of propanidid on sympathetic nervous activity and pulse rate in a hypertensive cat (No. 21). Hypertension created by injection of nor-epinephrine prevented reduction of arterial pressure by propanidid below the initial level, but despite reduced sympathetic tone a marked increase in pulse rate occurred.

\section{Denervated animals}

The effect of propanidid on sympathetic nervous activity and pulse rate in these animals was quite different from that found in normal animals (Figures 1 and 3). Sympathetic nervous activity declined without any initial rise from $58.0 \pm 5.8$ to $33.0 \pm 5.7$ impulses $/ \mathrm{sec}(\mathrm{p}<0.001)$ and did not recover to a level not significantly different from the initial until $7 \frac{1}{2}$ minutes later.

Pulse rate declined from $215.3 \pm 19.3$ to $205.2 \pm 18.4$ beats $/ \mathrm{min}$ and returned to the initial level within one minute, but in no instance was an increase in pulse rate noted.

Mean arterial pressure declined from $133.1 \pm 12.2$ torr $(17.7 \pm 1.7 \mathrm{kPa})$ to $58.1 \pm 4.5$ torr $(7.7 \pm 0.6 \mathrm{kPa})(p<0.001)$ and recovered within two minutes. In comparison with normal animals propanidid reduced arterial pressure significantly more in denervated animals (to $45.8 \pm 3.4$ per cent of initial versus $69.0 \pm 3.8$ per cent; $p<0.01$ ) than in normal animals. No overshoot in arterial pressure after the initial decline was noted in these animals.

\section{Decerebrate animals}

The two decerebrate animals reacted to propanidid in the same way as did the normal animals. Mean arterial pressure declined, sympathetic nervous activity increased initially, followed by a moderate decline, and pulse rate increased markedly.

\section{Vagal animals}

Four experiments were performed in two animals with first one and then both vagal nerves sectioned. With one vagal nerve sectioned pulse rate increased from 151 to 182 and from 157 to 199 beats/min and with both vagi sectioned the pulse rate still increased from 203 to 217 and from 207 to 230 beats $/ \mathrm{min}$. 


\section{Hypertensive animals}

Figure 4 illustrates a typical experiment. By intravenous administration of norepinephrine we prevented any decline in arterial pressure below the initial level after the injection of propanidid. A depression in sympathetic nervous activity was observed, but nevertheless the pulse rate invariably increased.

\section{Discussion}

Our primary objective was to study the effects of propanidid on the circulatory control mechanisms by a method previously used in studies of short-acting barbiturates and Althesin. This would enable us to make a comparison between these three chemically different induction agents. Like barbiturates and Althesin, propanidid produced a marked depression in arterial pressure. With short-acting barbiturates a depression of sympathetic nervous activity was found to be a probable cause of the decline of blood pressure, since sympathetic nervous activity closely mimicked the changes in arterial pressure during both induction and recovery. ${ }^{5}$ With Althesin, sympathetic nervous system depression could only in part explain the decline in blood pressure because arterial pressure recovered at a time when sympathetic nervous activity was still depressed. With propanidid, hypotension occurred despite an increase in sympathetic nervous activity.

Åström, Bernhoff, Persson ${ }^{8}$ found a direct negative chronotropic and inotropic effect of propanidid on isolated hearts. Bernhoff, et al. ${ }^{2}$ found propanidid to produce a clearcut negative inotropic effect in man as indicated by hypotension as well as increased left atrial pressures. A diminished total peripheral resistance was also observed. In addition propanidid has been found to decrease total peripheral resistance in the studies by Sankava ${ }^{9}$ and by Tsunawaki and associates. ${ }^{10}$ These studies, showing propanidid to produce both myocardial depression and vasodilatation, explain the hypotension always found after propanidid in this study. The fact that decerebrate animals reacted to propanidid as did normal ones excludes any major action of propanidid on autonomic nervous centres above the medulla oblongata. The depression of sympathetic nervous activity found in baroreceptor denervated animals and to a lesser degree in the normal animals after an initial increase is to us an indication that propanidid causes some depression of the pressor neurons of the vasomotor centre. The finding of an increase of sympathetic nervous activity coinciding with a decline in arterial pressure indicates active barostatic reflexes. In support of this are our findings in baroreceptor denervated animals (no barostatic reflexes) where sympathetic tone never increased in spite of marked hypotension.

The reflex induced increase in sympathetic tone explains in part why tachycardia was seen after sectioning of the vagal nerves. Since several investigators have found propanidid to produce both hypotension and tachycardia, ${ }^{\mathbf{9}, 311}$ findings similar to ours in normal animals, we tried to examine the cause of the tachycardia produced by propanidid. Tachycardia was never observed in baroreceptor denervated animals, an observation supporting the findings of $\AA$ ström, et al..$^{8}$ of a direct negative chronotropic effect of propanidid on the heart. To examine if the tachycardia seen in normal animals was caused by factors other than the increased 
sympathetic tone, propanidid was administered with quantities of norepinephrine sufficient to prevent any decline in arterial pressure below initial levels. The result obtained was a sympathetic depression substantiating our previous statement about unaffected barostatic reflexes. A marked increase in pulse rate was observed despite depressed sympathetic tone, indicating a vagolytic action of propanidid most likely of peripheral origin.

Our finding of significantly increased depression of arterial pressure when barostatic reflexes are absent (denervated animals) indicates the importance of normal barostatic reflexes in preventing excessive cardiovascular depression following the administration of propanidid. In contrast to our findings in previous studies on the effects of short acting barbiturates and Althesin on central circulatory control mechanisms, where at least part of the cardiovascular depression could be explained on the basis of a depressed sympathetic tone, propanidid appears to exert its depressant action directly on the cardiovascular system.

The central circulatory control mechanisms are essentially unaffected and act to minimize the direct cardiovascular depressant action of propanidid.

The clinical implication of our findings is that an extraordinary degree of hypotension is to be expected when propanidid is administered to patients where barostatic reflexes are impaired. This does not only imply patients with orthostatic hypotension, but also patients in whom a sympathetic block is produced, as with spinal or epidural anaesthesia. Also patients unable to respond to an increased sympathetic tone, as when $\alpha$ or $\beta$ receptor blocking agents have been administered, should be expected to react to propanidid with severe hypotension. Likewise propanidid should be expected to produce excessive cardiovascular depression due to its vagolytic action in situations where tachycardia might be deleterious, as in patients with valvular heart disease.

\section{SUMMARY}

We have studied the effects of propanidid on preganglionic cervical sympathetic nervous activity, arterial pressure, pulse rate and barostatic reflexes of the cat. Normal, hypertensive, baroreceptor denervated and decerebrate animals with sectioned vagal nerves were studied. On the basis of our findings it is concluded that propanidid exerts its depressant action on the cardiovascular system directly. Central circulatory control mechanisms are essentially unaffected. The depression of arterial pressure caused by propanidid is moderated by two compensatory mechanisms: normal barostatic reflexes causing an increased sympathetic tone in response to hypotension and a vagolytic action of propanidid.

\section{RÉSUMÉ}

Nous avons étudié les effets du Propanidid sur l'activité sympathique préganglionnaire cervicale, sur la pression artérielle, la fréquence cardiaque et les mécanismes barorécepteurs. A cet effet, nous avons utilisé cet agent chez le chat normal, le chat hypertendu, le chat décérébré et l'animal privé de son mécanisme barorécepteur. 
Nos résultats nous amènent à conclure que le Propanidid déprime le système cardiovasculaire par action directe. Les mécanismes centraux de contrôle cardiovasculaire ne sont pas affectés. Par ailleurs, la diminution de pression artérielle causée par le Propanidid est partiellement compensée par deux mécanismes, à savoir le maintien de l'activité baroréceptrice permettant une augmentation du tonus sympathique en réponse à l'hypotension et, par une action vagolytique du Propanidid.

\section{ACKNOWLEDGMENTS}

The authors acknowledge the assistance of Henry L. Price, M.D., Professor, Chairman and Research Director of the Department for his advice and support during the conduct of the study, Mr. Leo Davidson for his able technical assistance and Jonathan Korshin, M.D., for his assistance in preparation of the manuscript.

\section{REFERENCES}

1. Doenicke, A., Krumey, I., Kugleh, J., \& Klempa, J. Experimental studies of the breakdown of Epontol: determination of propanidid in human serum. Br. J. Anaesth. 40: 415 (1968).

2. Bennhoff, A., EkLund, B., \& Kaljser, L. Cardiovascular effects of short-term anaesthesia with methohexitone and propanidid in normal subjects. Br. J. Anaesth. 44: 2 (1972).

3. Johnstone, M. \& Barron, P.T. The cardiovascular effects of propanidid. A study in radiotelemetry. Anaesthesia 23: 180 (1968).

4. Soga, D., Beer, R., Bader, B., Andrae, J., \& Götz, E. Die Beeinflussung der linksventriculären Myokardcontractilität und Hämodynamik durch Propanidid beim Menschen. In: Zindler, M., Yamamura, H., \& Wirth, W.: Intravenöse Narkose mit Propanidid. Ist ed. Berlin, Heidelberg, New York: Springer-Verlag, p. 78 (1973).

5. Skovsted, P., Phice, M.L., \& Price, H.L. The effects of short-acting barbiturates on arterial pressure, preganglionic sympathetic activity and barostatic reflexes. Anesthesiology 33: $10(1970)$.

6. Sapthavichaikul, S., Wisbong, K., \& Skovsted, P. The effects of Althesin on arterial pressure, pulse rate, preganglionic sympathetic activity and barostatic reflexes in cats. Canad. Anaesth. Soc. J. 22: 587 (1975).

7. Skovsted, P., Price, M.L., \& Price, H.L. The effects of halothane on arterial pressure, preganglionic sympathetic activity and barostatic reflexes. Anesthesiology 31:507 (1969).

8. Aström, A., Bernhoff, A., \& Persson, N.-A. Effects of propanidid (Epontol(i) and methohexital (Brietal(1)) on the contractile force of the isolated guinea-pig heart. Acta anaesth. scand. 14: 45 (1970).

9. Sankawa, H. Cardiovascular effects of propanidid and methohexital sodium in dogs. Acta anaesth. scand. suppl. XVII: 55 (1965).

10. Tsunawaki, H., Kobayashi, K., Sari, A., Okuda, Y., \& Takeshita, H. Hemodynamic effects of propanidid in man. Acta anaesth. scand. 17:70 (1973).

11. Wynands, J.E. \& Burfoot, M.F. A clinical study of propanidid (FBA 1420). Canad. Anaesth. Soc. J. 12: 587 (1965). 